This is a self-archived version of an original article. This version may differ from the original in pagination and typographic details.

Author(s): Stucki, Tobias

Title: What hampers green product innovation : the effect of experience

Year: 2019

Version: Accepted version (Final draft)

Copyright: (c) 2019 Informa UK Limited, trading as Taylor \& Francis Group.

Rights: In Copyright

Rights url: http://rightsstatements.org/page/lnC/1.0/?language=en

Please cite the original version:

Stucki, T. (2019). What hampers green product innovation : the effect of experience. Industry and Innovation, 26(10), 1242-1270. https://doi.org/10.1080/13662716.2019.1611417 


\title{
What Hampers Green Product Innovation: The Effect of Experience
}

\author{
Tobias Stucki ${ }^{1}$
}

Draft version. Final version forthcoming in Industry and Innovation

\begin{abstract}
:
Based on representative firm-level survey data for Austria, Germany, and Switzerland, this study systematically analyzes the relevance and drivers of barriers to green product innovation using the example of green energy technologies. "Low willingness to pay", "high development costs", "high commercial uncertainty", and "lack of favorable political framework" are identified as the most important barriers. Moreover, we find that the firms' innovation experience is an important driver of the level of green innovation barriers. Green innovation barriers are more accentuated for firms with green innovation activity than for firms with no green innovation activity. However, experience from different fields of green innovation and experience from non-green innovation activities help to limit these barriers.
\end{abstract}

Keywords: Energy technologies; green innovation; hampering factors; innovation barriers; innovation experience.

JEL classification: O30; O34; Q55.

${ }^{1}$ Bern University of Applied Sciences, Business department, Bern, Switzerland; University of Jyväskylä, Business and Economics department, Jyväskylä. Finland. tobias.stucki@bfh.ch; The author gratefully acknowledges financial support from the Swiss National Science Foundation (SNSF; award number: P300P1_164602) and thanks the editor and two anonymous referees of this journal for useful comments and suggestions. 


\section{Introduction}

Significant technological development of both existing and new green technologies is required to seriously deal with climate change (IPCC 2014). However, it still does not seem to be very attractive to invest in the creation of green technologies, as returns to such investments tend to be lower than for non-green technologies (see Marin 2014, Soltmann et al. 2015, Van Leeuwen and Mohnen 2017). To be able to make the creation of green technologies more attractive to the private sector, it is thus worthwhile to take a closer look at what hampers green innovation.

Innovation barriers have been extensively analyzed for general innovation (Blanchard et al. 2013, D’Este et al. 2012, Galia and Legros 2004, Mohnen and Röller 2005). In this study, we extend this research by focusing on barriers to green product innovation and empirically testing our theoretical predications using the example of green energy technologies. ${ }^{1}$ Green energy technologies are defined in our setting as (a) product innovation activities for the generation of energy saving technology for end-user in one of the following areas: production, ICT, transport or building technology; and (b) product innovation activities for the generation of technology for the use of energy from renewable sources, such as wind or hydroelectric power plants or solar systems.

Although we already have quite some knowledge about innovation barriers in general, it makes sense to take a closer look at the barriers of green innovation. First, due to the different characteristics of green innovation compared to non-green innovation, the relevance of innovation barriers may be significantly different for green innovation. In addition, our data set allows us to examine barriers that directly refer to the specificity of green innovation, such as the low willingness to pay, the high complexity, or the early stage of the technology, which are not explicitly considered in traditional innovation surveys such as the Community Innovation Survey (CIS).

\footnotetext{
${ }^{1}$ The general problem of green technologies as a whole does not differ significantly from that of green energy technologies. Accordingly, there is little evidence that the innovation barriers vary significantly between different types of green innovation. In our empirical model, green energy technologies are therefore regarded as an example of green technologies as a whole. Nevertheless, we must admit that there is a possibility that barriers may differ between different types of green innovation. Whether this is effectively the case should be checked in future studies.
} 
Second, it is especially important for green innovation to better understand the drivers of the innovation barriers. Only if we know which companies are primarily affected by these barriers, we can also identify hampered companies and address their problems. In this paper, we analyze two factors that have not been analyzed before for either general or green innovation activities: (a) we investigate whether experience in many green technology fields allows the firms to learn; if this is the case, broad green innovation experience should significantly reduce the firms' perceived innovation barriers. And (b) we test whether it is possible to transfer knowledge from non-green innovation activity to green innovation activity; if this applies, experience in non-green innovation activity should reduce the impact of green innovation activity on the perception of green innovation barriers in an enterprise. In sum, the barriers to green innovation, even if considerable, should thus at least decrease as innovation experience increases.

The green innovation literature names several reasons why it may not pay off for a firm to invest in the creation of green technologies, such as a low willingness to pay, lack of knowledge, or lack of financing (e.g., Aghion et al. 2009, Soltmann et al. 2015). However, in contrast to general innovation, the relevance and drivers of different hampering factors of green product innovation has not been explicitly analyzed based on a broad empirical basis. Costa-Campi et al. (2014) analyze innovation barriers in the energy sector, and Souto and Rodriguez (2015) investigate differences between innovation barriers for firms with and without green innovation activities. However, in contrast to our study, both studies focus on general innovation barriers and do not consider specific barriers to green innovation. Moreover, their information on innovation barriers refers to the firms' innovation activities in general, which is typically dominated by non-green innovation activities. ${ }^{2}$ Our information directly refers to green innovation activity. Probably most related to our study, Ghisetti et al. (2017) analyze the effect of financial barriers for environmental innovation based on specific firm-level survey data for SMEs in EU-27 countries. Although, their

\footnotetext{
${ }^{2}$ In our sample referring to green innovation, the average share of green innovation activities in total innovation activities (restricted to companies with green innovation activities) is $11 \%$, and only $6 \%$ of the firms with green innovation activities have more green than non-green innovation activities.
} 
information on innovation barriers specifically refers to green innovation activities, the focus of their paper is on financial constraints. We choose a broader approach. Besides lack of financing, eight other potential green innovation barriers are considered in our setting. Moreover, our focus is in analyzing the drivers of the barriers rather than their impact on outcome variables. Finally, Marin et al. (2015) used the same data set of SMEs from 27-EU countries to identify different firm profiles based on their perceived green innovation barriers and their actual engagement in green innovation activities. In contrast to their study, we investigate the impact of innovation activity on green innovation barriers in more detail, e.g., by analyzing how knowledge from different technology fields of green innovation activities or knowledge from non-green innovation activity affect green innovation barriers.

To analyze green innovation barriers, we make use of a unique firm level data set for the three countries Germany, Austria and Switzerland. To obtain representative information, the data is based on firm samples that are representative for the firm population of each of the three countries. The data includes information on the firms' assessments of the relevance of nine different barriers frequently discussed in the green innovation literature. Moreover, the data set includes a broad set of other firm-level information, which makes it possible to test potential drivers of green innovation barriers.

This paper is organized as follows: in Section 2 the conceptual background is presented. In Section 3 we present the data. In Section 4 we explain the empirical testing. The results are presented in Section 5 and discussed (including possible policy implications) in Section 6. Section 7 concludes the paper.

\section{Conceptual framework}

\subsection{Green vs. non-green innovation}

In order to understand the importance of different green innovation barriers, we first outline how green innovation differs from non-green innovation. A first characteristic of green innovation is 
complexity. Green innovation activity is typically more complex than non-green innovation activity and challenges a firm's capability profile in terms of knowledge creation and technology development (Soltmann et al. 2015). Green innovation activities usually lie beyond the traditional technological scope of the companies (Shrivastava 1995) and typically require a restructuring of the entire organizational structure of a company (Noci and Verganti 1999). Business processes and working routines have to be adapted or even newly developed (Danneels 2002). Moreover, green innovation is on average characterized by a higher degree of novelty, uncertainty and diversity compared to the traditional technology or market area in which the company normally competes (Cainelli et al. 2015).

In addition, green innovation differs from non-green innovation because it suffers from a ‘double externality’ problem (Rennings 2000). First, green innovation activities, as innovation activities in general, are exposed to negative externalities, since knowledge from innovation activities can diffuse to other market participants. In comparison with non-green innovation, however, green innovation faces a second externality problem. A specificity of green innovation is that it leads to a reduction in the production of negative environmental externalities. While the reduction of such environmental externalities is beneficial for the society as a whole, the customers are (typically) not willing to pay for these improvements. In the end, this often implies that the willingness to pay for green innovation is lower than for non-green innovation (Hall and Helmers 2013).

The higher complexity and the lower willingness to pay do not necessarily mean that it generally does not pay off to invest in green innovation (some evidence that it may pay off to invest in green technologies, e.g., can be found in Ghisetti and Rennings 2014, Rexhäuser and Rammer 2014, Van Leeuwen and Mohnen 2017). However, in addition to these two problems, green innovation is also often affected by market imperfections, such as organizational inertia, control problems, or asymmetric information (Rubashkina et al. 2015). Such market imperfections make it difficult for companies to understand the full cost of incomplete resource use and thus to identify 
profit opportunities from the generation and use of green technologies. As a result, companies may not invest in green technologies even though it would pay off financially.

All in all, these specific characteristics of green innovation lead to a higher dependence on policy action compared to non-green innovation. This is either to compensate for the cost of complexity and the low willingness to pay or to inform companies about likely resource inefficiencies and make green innovation more attractive to them (Berrone et al. 2013; Costantini et al. 2015; Jaffe et al. 2005; Porter and van der Linde 1995; Stucki et al. 2018).

Overall, this discussion shows that it makes sense to examine the barriers to green innovation more closely. Due to the specific problems of green innovation, however, it is hardly possible to compare the barriers 1:1 with non-green innovation. ${ }^{3}$ For this reason, our study will focus mainly on green innovation and take up possible differences to non-green innovation in the discussion of the results.

\subsection{Barriers to green innovation}

The main determinants of general innovation activities are appropriability of research results, firm size, competition, demand, and the technological potential (Cohen 2010). With the exception of environmental policy, which is an important driver of green innovation due to its specific characteristics, the expected drivers of green innovation are largely the same as for non-green innovation (Horbach 2008). Rennings (2000) distinguishes three different groups of determinants of green innovation: (a) technology-push factors (i.e., supply-side drivers), (b) demand factors (i.e., demand-side drivers), and (c) the regulatory framework (i.e., policy).

Innovation barriers can basically be interpreted as a lack of important drivers of innovation. Hence, not only the drivers but also the type of innovation barriers should be largely the same for

\footnotetext{
${ }^{3}$ Since there are hardly any companies that exclusively pursue green innovation (see footnote 2), information on the firms' general innovation activities would likely refer primarily to non-green innovation. To deal with this fact, the data used for this study refer specifically to green innovation. Regarding the innovation barriers, barriers specifically relevant to green innovation were surveyed and their relevance was specifically recorded for the firms' green innovation activity (see Tables A.1 and A.2 in the Appendix). As a result, however, we cannot directly compare green and non-green innovation barriers.
} 
both green and non-green innovation. However, the specific characteristics of green innovation should lead to shifts in the importance of certain innovation barriers. Because of the strong dependence on environmental policy, political barriers are likely to be more important for green innovation. In addition, the greater complexity of green innovation is likely to lead to the accentuation of certain barriers on the supply side. Finally, the double externality problem is likely to affect also the barriers on the demand side.

Most existing studies in the general innovation literature tend to focus on the effects of financial obstacles (Canepa and Stoneman 2007; Hall, 2002; Hottenrott and Peters 2012; Hyytinen and Toivanen 2005; Savignac 2008), but other demand- and supply-side factors have been analyzed as well such as factors related to knowledge and capabilities, market structure and regulations (D'Este et al. 2012; Iammarino et al. 2009; Mohnen et al. 2008; Pellegrino and Savona 2017).

In this study, we try to present a complete picture of innovation barriers that are expected to be particularly important for green innovation. Following Rennings (2000), we distinguish between (a) supply-side, (b) demand-side and (c) political factors. An overview is presented in Figure 1. A first potential barrier to green innovation on the supply side is the high development costs of such innovation activity. The costs of green innovation can be considerable, as the creation of green technologies typically requires investing in technologies that lie beyond the firm's traditional technological scope (Shrivastava 1995). Moreover, in addition to technology, business processes and working routines also have to be adapted or even newly developed, which further increases costs in the initial phase (Danneels 2002). Second, besides the high costs of green innovation, the creation of green technologies challenges a firm's capability profile in terms of knowledge creation and technology development. Green jobs generally require more intensive cognitive and interpersonal skills at a high level than non-green jobs, which can lead to lack of knowledge, respectively lack of qualified personnel (Consoli et al. 2016). This problem may be especially relevant as internal knowledge sources typically have greater importance for green 
innovations (Cainelli et al. 2015). Third, not only the personnel but also the management is confronted with increasing complexity. The introduction of green products requires the involvement of all the organizational unity of the corporate management system, and entail actions on the whole supply chain (Noci and Verganti 1999). Hence, the introduction of green products is a complex challenge for the management, which requires sufficient management capacity. A fourth factor that may hamper green innovation are potential technological gaps. To create green innovation, primarily internal green knowledge is required. This makes it difficult to catch up technologically, once the gap to the technological leader is too large (Stucki and Woerter 2017). Fifth, due to the high technological risk of green innovation, the financing of green innovation may be even more difficult than for non-green innovation activities (see Arrow 1962), which may result in lack of financing (Cuerva et al. 2014; Ghisetti et al. 2017).

Besides potential barriers on the supply side, several factors on the demand side may hamper
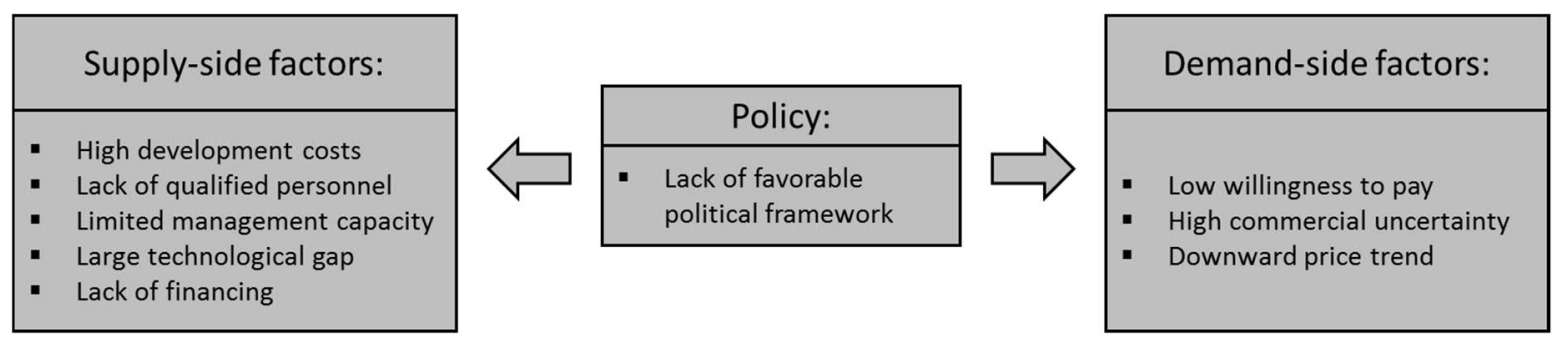

Figure 1: Types of green innovation barriers

green innovation. First, compared to non-green innovation, the greatest benefits from green innovation flow largely to those who do not bear the costs. Hence, the willingness to pay for green products is typically low (Hall and Helmers 2013, Stucki 2019). Second, the strong dependency of green products on policy interventions leads to another potential demand side barrier, as it makes the demand for green innovation very volatile, which may significantly increase commercial uncertainty, and thus decrease the firms' willingness to invest in green innovation (Aghion et al. 2009, Stucki and Woerter 2018). Finally, since it takes a certain time to bring a new product to market, innovation decisions are not only affected by the current price level but also by the development of the price over time. Hence, downward price trends are expected to reduce the 
incentives to innovate. Such price decreases are often observed in new markets as a consequence of new process innovations (Agarwal and Bayus 2002), and are also observed on green markets like the markets for solar photovoltaic (Reichelstein and Yorston 2013) and wind energy installations (Berry 2009).

Policy intervention may help to overcome the externality problem in the market for green products, either on the demand side by financially internalizing the environmental costs or by imposing a limit on the level of environmental pollution (Popp et al. 2010), or on the supply side by financially supporting green innovation activity (Nemet 2009). If such policy measures are lacking, this can be seen as another barrier to green innovation.

\subsection{Drivers of perceived green innovation barriers}

So far, we discussed potential barriers to green innovation. However, to be able to identify hampered firms and address their problems, we also need to know which firms are primarily affected by these barriers. The firms' innovation activity and their innovation experience may be important indicators for the companies' perceived innovation barriers.

\subsubsection{Perceived innovation barriers vis-à-vis innovation activity}

Intuitively, one would expect that innovation barriers prevent a firm's engagement in innovation activity. Hence, the correlation between innovation barriers and a firm's innovation activities should be negative. D'Este et al. (2012) call this the 'deterring effect' of innovation barriers. Besides this deterring effect, however, they also identified a 'revealed effect' of innovation barriers, which results in a positive correlation between innovation barriers and innovation activity. This positive correlation can be explained by the fact that innovation activity makes it more likely that a firm perceives the various obstacles that stand in their way (Mohnen et al. 2008). Engagement in innovation activity thus increases a firm's awareness of the associated difficulties, but barriers do not prevent them from engaging in innovation activities or being successful innovators (D'Este et al. 2012). 
Existing studies typically find a positive correlation between innovation and perceived barriers (see Hottenrott and Peters 2012 for Germany; D'Este et al. $2012^{4}$ for UK; Baldwin and Lin 2002 and Mohnen and Rosa 2001 for Canada; Iammarino et al. 2009 for Italy). Hence, the 'revealed effect' of innovation barriers seems to dominate. We therefore assume that green innovation is also positively correlated with the perceived green innovation barriers of companies.

Based on the existing literature, such a positive correlation between green innovation activity and green innovation barriers can be expected on average across all barriers. However, the direction of this correlation may differ between different types of barriers. D'Este et al. (2012) find that particularly in the case of market barriers, the deterring effect seems to be very pronounced, which can lead to a negative correlation with the innovation activity of companies. Accordingly, it is important to consider the innovation barriers not only in an aggregated way, but also to examine possible differences between the barriers.

Moreover, Pellegrino and Savona (2017) argue that the identification of a positive correlation between innovation barriers and innovation activity may be driven by an inappropriate selection of the relevant sample. After adjusting the identification of potential innovators, they observe negative correlations between most barriers and the firms' innovation activities (see also Ghisetti et al. 2017 for a related finding). In order to avoid such a selection bias, we must therefore be particularly careful when selecting the sample (see Section 3).

Hypothesis 1: Engaging in green innovation increases firms' perception of green innovation barriers.

\footnotetext{
${ }^{4}$ In contrast to this paper, D'Este et al. (2012) used information on the firms' effective numbers of innovation activities, which facilitates the separate identification of the deterring and revealed effects of innovation barriers. While the deterring effect occurs primarily in the transition from no innovation activity to a certain number of innovation activities, the revealed effect is primarily observed in the expansion of the number of innovation activities. However, the results in D'Este et al. (2012) also indicate that if one did not distinguish between the different number of innovation activities, the effect of innovation activities would be positive on average for most barriers.
} 


\subsubsection{Perceived innovation barriers vis-à-vis innovation experience}

According to the learning curve, production costs fall as firms gain experience in production. Wright (1936) was the first to empirically document such a learning curve, which has been verified by many other studies (see reviews by Yelle 1979, Dutton and Thomas 1984). Pruett and Thomas (2008) shifted the concept of the learning curve to innovation activities by arguing that innovation experience should enable learning and improve a firm's innovation capability.

A rather similar argument can be made based on the resource-based view literature. According to the resource-based view, a direct link is assumed between a firm's sustained competitive advantage and its valuable, rare, imperfectly imitable, and non-sustainable resources and capabilities, such as management skills, organizational processes and routines, and the information and knowledge it controls (Barney 1991; Barney et al. 2001). Hence, related to the learning curve literature, the resource-based view indicates that companies with a lot of innovation experience have more resources for innovation and thus a higher innovation capability.

But what drives a firm's innovation experience? The literature remains rather vague in this respect. This paper distinguishes between two forms of innovation experience: (a) the experience of the companies in different fields of green innovation, i.e. their breadth of experience, and (b) their experience in non-green innovation activities. Both types of experience are expected to reduce the firms' perceived green innovation barriers. ${ }^{5}$

\section{Learning from different technology fields of green innovation activity}

In this paper, we argue that the innovation experience of a company is dependent on the number of technology fields in which a company is operating. In the patent literature, patents are assigned to different technology fields. Based on an OECD classification, for example, patents can be

\footnotetext{
${ }^{5}$ In addition to these two types, one can also imagine other forms of experience that could influence green innovation barriers. For example, experience from intensive innovation activity within a particular field of green innovation should also reduce innovation barriers. In order to identify such an effect, however, a relatively large variance in innovation activity within a certain field is required. Unfortunately, this is not the case in our data set. Tests based on our data set have shown that although the results point in the expected direction for experience within a particular field, the effects cannot be significantly identified (results are available on request).
} 
assigned to many different green technology fields such as patents dealing with emission abatement and fuel efficiency in transportation, patents dealing with energy efficiency in buildings and lightning or patents dealing with renewable energy generation (OECD 2012). Knowledge in all these technology fields can be grouped together and form a single stock of green knowledge (Aghion et al. 2016; Ley et al. 2016). This requires that knowledge in a specific field of green technology can be transferred to other fields of green technologies. Or in the word of the learning theory, learning in a certain field of green technologies should improve innovation capability in another green technology field. Simultaneous innovation activity in different fields of green technology should therefore lead to synergies and increase the general green innovation capability of companies.

Firms with innovation experience in multiple technology fields of green innovation, i.e., firms with broad green innovation experience, are thus expected to have a higher capability to create new green technologies. In addition to an increased green innovation capability, such broad green innovation experience should more generally also reduce a firm's green innovation barriers, as innovation barriers should be similar for different technology fields of green innovation activity. Broad green innovation experience should reduce innovation barriers on the supply side, for example, by reducing development costs or by reducing a potential technological gap. Moreover, broad green innovation experience should also reduce demand side barriers, for example, by increasing a firm's knowledge on how to deal with high commercial uncertainty or how to deal with green policy.

Based on hypothesis 1, we expect that an expansion of green innovation activities leads to a higher awareness, i.e., a 'revealed effect', of green innovation barriers. However, as it is expected that firms learn from the experience in different technology fields of green innovation, it can be assumed that the barriers do not increase linearly as the breadth of green innovation activities increases but will stagnate or even decrease once a company has reached a certain breadth of green innovation activity. 
Hypothesis 2: The number of technology fields in which a company has green innovation activities has an inverted U-shaped effect on its perception of green innovation barriers.

\section{Learning from non-green innovation activity}

A specificity of knowledge is that not all results from knowledge production activities are appropriable. Hence, knowledge can spill over between firms, but also within firms from one program to another (Henderson and Cockburn 1996). Knowledge is also expected to spill over between green and non-green innovation activities. Since most green technologies are in a rather early phase of development, knowledge and experiences in non-green innovation activities are likely to play an important role for green innovation activities (Stucki and Woerter 2017). Hence, not only green-specific innovation experience, but also non-green innovation experience should enable learning and improve a firm's green innovation capability.

As discussed before, the type of innovation barriers should be similar for both green and nongreen innovation. With respect to green innovation barriers, we thus expect that firms with nongreen innovation activity should already be aware of potential barriers to green innovation. Hence, not only knowledge in innovation activity in general, but also knowledge regarding potential innovation barriers should spill over between green and non-green innovation. Accordingly, in addition to the experience of companies in different technology fields of green innovation activity (hypothesis 2), their experience with non-green innovation activities should also reduce the 'revealed effect' of green innovation barriers. Hence, the firms' non-green innovation experience should act as an important moderator of the effect of green innovation on perceived green innovation barriers.

Hypothesis 3: Non-green innovation activity reduces the effect of green innovation activity on a firm's perception of green innovation barriers. 


\section{Data}

The empirical testing of the predicted relationship is based on firm-level data that were collected in the course of a survey on the "creation and adoption of energy related technologies" carried out in the three countries Austria, Germany and Switzerland in 2015. Concretely, green product innovation was defined as the creation of energy saving technology/service and technology/service for the generation of energy from renewable sources for end-user. To obtain representative results, the survey was based on firm samples that are representative for the firm population of each of the three countries, i.e., the WIFO Enterprise Panel for Austria, the ZEW Enterprise Panel for Germany and the KOF Enterprise Panel for Switzerland. All these samples are stratified at the two-digit industry level and at three industry-specific firm size classes (with full coverage of large firms). Concretely the survey was sent to 6,374 German firms, 7,091 Austrian firms, and 5,789 Swiss firms. Valid information was received for 2,321 German firms (response rate: 36.4\%), 539 Austrian firms (7.6\%), and 1,815 Swiss firms (31.4\%). Given the very demanding questionnaire, the response rates for Germany and Switzerland are satisfying, but disappointing for Austria. However, a comprehensive recall action in all three countries ensured that a sufficient large number of answers was received for all three counties, covering all industries and all firm size classes according to the underlying sampling schemes. ${ }^{6}$

Besides questions on some basic firm characteristics (sales, exports, employment, investment and employees' education), the survey included questions on green energy related adoption and product innovation activities as well as on the firms' energy costs. Descriptive statistics for all model variables based on the estimation sample are presented in Table A.3 in the Appendix; the correlation matrix is shown in Table A.4.

Related to the Community Innovation Survey (CIS) for innovation activities in general, the survey also includes a specific set of questions that directly asked the firms to assess the relevance

\footnotetext{
${ }^{6}$ See Arvanitis et al. (2016) for further sample information.
} 
of different potential barriers for the start or the increase of their green energy product innovation activity (four-point Likert scale; level 1: 'not relevant'; level 4: 'high relevance'). In line with the discussion before, the following nine barriers have been considered: (1) high development costs, (2) lack of qualified personnel, (3) limited management capacity, (4) large technological gap, (5) lack of financing, (6) lack of favorable political framework, (7) low willingness to pay, (8) high commercial uncertainty, and (9) downward technology price trend.

\section{Identifying potential green innovators}

Only potential green innovators are aware of potential green innovation barriers. Hence, to be able to properly analyze green innovation barriers, we first have to select the relevant sample of firms. This step is of crucial importance because previous studies find that an inappropriate selection of the relevant sample can make the correlation between innovation activity and innovation barriers even point in the wrong direction (Pellegrino and Savona 2017). We do this in three steps. A first selection is made based on the firms' industry affiliation. Firms in certain industries may adopt green energy technologies but are rather unlikely to generate such technologies or services for endusers. Hence, we restrict our sample to the whole manufacturing sector (excluding the food industry, textile and cloth industry, printing, pharmaceuticals, and 'other manufacturing') and firms belonging to the two service industries 'information technology services' and 'technical services'. ${ }^{7}$ Based on this selection, we exclude $53 \%$ of the firms from our analysis; 2,186 firms remain in our sample. ${ }^{8}$ There are, however, even within these industries some firms, which have products or services that are not suitable for green product innovation. In order to identify these firms, we make use of a question that directly asked the firms whether their products are suitable

\footnotetext{
${ }^{7}$ Based on a previous survey, Arvanitis and Ley (2010) found that all other industries are unlikely to create themselves new green energy technologies for end-user, but primarily adopt green energy technologies developed by other firms (or generate green technologies not directly related to energy, such as technologies to reduce water pollution).

${ }^{8}$ To reduce confusion and maximize the response rate, a shortened version of the questionnaire was sent to firms that belong to the excluded industries, which includes questions regarding the adoption of green technologies, but not the generation of such technologies. Hence, this first sample restriction was made before sending the survey to the firms.
} 
for green innovation or not. Only firms with suitable products are considered here. ${ }^{9}$ Based on this selection, we exclude another $14 \%$ of the firms from our analysis; 1,877 firms remain in our sample. Finally, the survey includes a question about whether the development of green technologies has already been under discussion or not. Companies without such discussions are excluded in a third step, since these firms will hardly be able to assess potential green innovation barriers. In addition, this variable seems to be a good proxy for the willingness of companies to engage in green innovation, which according to Pellegrino and Savona (2017) is a key characteristic of potential innovators. Based on this final selection, we drop another $48 \%$ of the firms; 972 observations remain in our final sample. The selection process shows that green product innovation is still not relevant for the majority of firms. In sum, only $21 \%$ of the firms are considered as potential green innovators. Only these potential green innovators are considered in our empirical tests (both description and empirical models). This also underscores the importance of having such a large initial sample of firms to properly investigate the barriers to green innovation.

46\% of the 972 firms are German firms, 13\% Austrian firms, and 41\% Swiss firms. On average, the firms in our sample have 314 employees (median: 57 employees), whereupon 83\% are SMEs with less than 250 employees. $77 \%$ of the firms belong to the manufacturing sector, $16 \%$ to the service sector and $7 \%$ to the construction sector.

\section{Empirical testing}

To test the relevance of the different hampering factors, we first present some descriptive statistics. After that, we try to characterize firms that are heavily hampered based on econometric regressions. In order to test our hypotheses, the focus is on how the firms' innovation activity affects the firms'

\footnotetext{
9 The information on the suitability of their products/services is based on a four-point Likert scale (first topic of question 5.6; see Table A.1 in the Appendix). Here, we dropped all firms, which assessed that lack of suitability is a highly relevant barrier. The results, however, look very similar, when we use a more restrictive definition (results are available on request).
} 
perceived green innovation barriers. As our hypotheses do not differentiate between different types of obstacles, we use in our main regressions an overall measure for the firms' perceived green innovation barriers. ${ }^{10}$ To aggregate the information on the different barriers, we construct a measure for the breadth of green innovation barriers as a combination of the nine barriers included in the survey. Each barrier is first coded as a binary variable, which takes the value 1 if the barrier is at least of "medium relevance" and the value 0 if it is "not relevant" or of "low relevance". ${ }^{11}$ To get the overall measure, all barriers are then summed up: firms that are not hampered by any barrier have a breadth equal to 0 , whereas firms which are hampered by all barriers have a breadth equal to 9 .

Thus, our overall measure is a count variable between 0 and 9. Obviously, this variable is restricted by an upper bound, making poisson or negative binomial distributions not applicable. To deal with this fact, we transform our breadth measure into a fraction variable by dividing the variable by the upper bound, which then allows us to estimate a fractional logit regression (Wooldridge 2002). Hence, our final overall measure used in the empirical analysis is a fractional variable between 0 and 1 .

To test the hypotheses empirically, we use three different innovation variables. First, to test hypothesis 1 , we use a measure for the firms' green innovation propensity. Second, to test the effect of the breadth of green innovation experience, as predicted in hypothesis 2 , we use information on the number of technology fields in which a firm has green innovation activities. Our data set allows us to distinguish the following technology fields: (a) production (e.g., electrical machines and drive systems), (b) information and communication technology (e.g., energy-saving servers), (c) transport (e.g., engines of motor vehicles, electric cars), (d) building technology (e.g., temperature isolation, lighting, heating, air ventilation), (e) green energy generation (e.g., photovoltaics, wind

\footnotetext{
${ }^{10}$ To test differences between different types of obstacles, we present in an extension also separate regressions for the different obstacles.

${ }^{11}$ We also tested alternative thresholds for the construction of the binary variables. The results were very similar (results are available on request).
} 
power, hydro-electric power stations). ${ }^{12}$ Third, to test the moderating effect of non-green innovation activities, we use information on the firms' non-green innovation sales per capita.

To reduce a potential omitted variable bias, we control in our model for several observables that describe firm and market characteristics and typically affect innovation activity. In line with D'Este et al. (2012) we control for firm age, export activity, whether the firm is foreign owned, firm size, country of origin and industry affiliation (see also Pelegrino and Savona 2017 for a similar model). The control for firm size is of special relevance, as small firms often face more severe constraints than large firms (Mohnen et al. 2008). Additional controls are tested in Table 3 and discussed in the robustness section. However, it is important to note that in our model we do not want to explain the green innovation activity of companies but characterize companies that are strongly affected by green innovation barriers. Nevertheless, we control in our model for important drivers of green innovation activity (see Horbach 2008). Due to missing values for some model variables, our final estimation sample includes 909 observations.

The analysis is based on cross-sectional data. Therefore, the potential problem of reverse causality cannot be solved, and we have to be cautious in interpreting the results. Hence, we refrain from making causal claims, but interpret the estimated coefficients as partial correlations, which still allows a characterization of the firms depending on the breadth of their green innovation barriers.

\section{Results}

The relevance of perceived green innovation barriers

\footnotetext{
${ }^{12}$ Ultimately, we do not know whether a company uses the same technology in several fields or not. Hence, our measure of technology fields may not adequately represent the firms' innovation experience. However, the definition of technology fields used is so heterogeneous that, from our point of view, it seems unlikely that a company would be active with the same technology in different fields. Accordingly, we are convinced that our variable not only measures diversification into different technological fields, but also measures a company's experience in different technological fields of green innovation.
} 
The relevance of the nine different green innovation barriers is presented in Figure 2. In a first step, we focus on the share of firms reporting at least "low relevance". "Low willingness to pay" is of some relevance for $62 \%$ of the firms. "High development costs", and "high commercial uncertainty" follow close behind with shares of 57\% and 55\%, respectively. "Lack of favorable political framework" (52\%) and "limited management capacity" (51\%) are still of some relevance for more than $50 \%$ of the firms. "Downward price trend" (46\%), "lack of qualified personnel" (42\%), and "lack of financing" (42\%) are of lower relevance. "Large technological gap" (31\%) shows the lowest relevance, but still is of some relevance for almost one third of the firms.

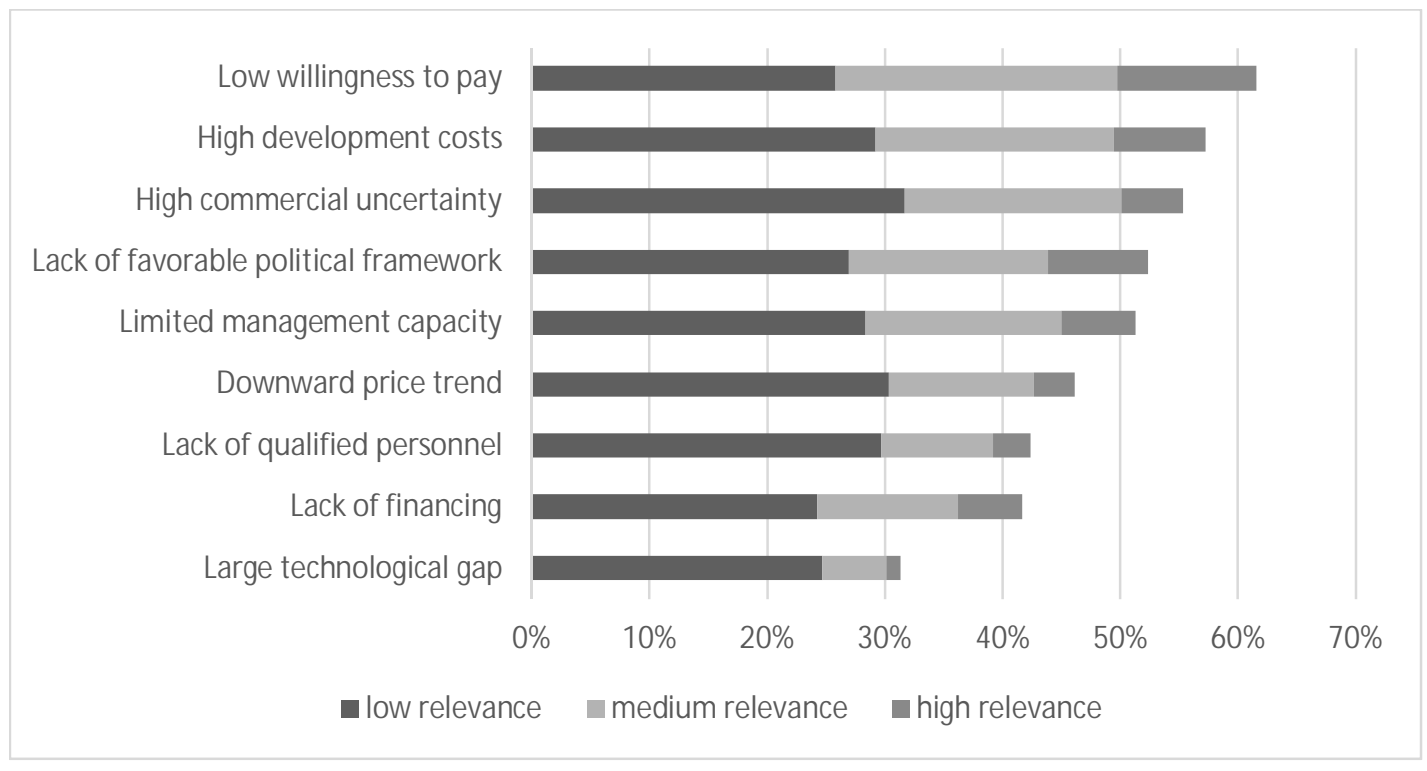

Figure 2: Relevance of perceived green innovation barriers

Overall, green product innovation activity is thus primarily hampered by a "low willingness to pay", "high development costs", "high commercial uncertainty", and "lack of favorable political framework". The picture changes only slightly, when we consider the obstacles' different levels of relevance. The only exceptions are "high commercial uncertainty", which becomes less important when focusing on firms with high relevance, and "lack of favorable political framework" and "lack of financing", which gain importance (see Figure 3).

Among the most important barriers are therefore demand-side, supply-side and political barriers. In general, however, demand-side barriers appear to be somewhat more relevant than 
supply-side barriers. Contrary to the strong importance of politics in the literature on green innovation, political barriers do not dominate in our sample.

The relative importance of the different barriers only slightly differs between the three countries (see Figure 3). What becomes obvious, however, is that the level of the barriers significantly differs between the countries. In general, Swiss firms seem to be more hampered than Austrian firms, which in turn are more hampered than German firms.

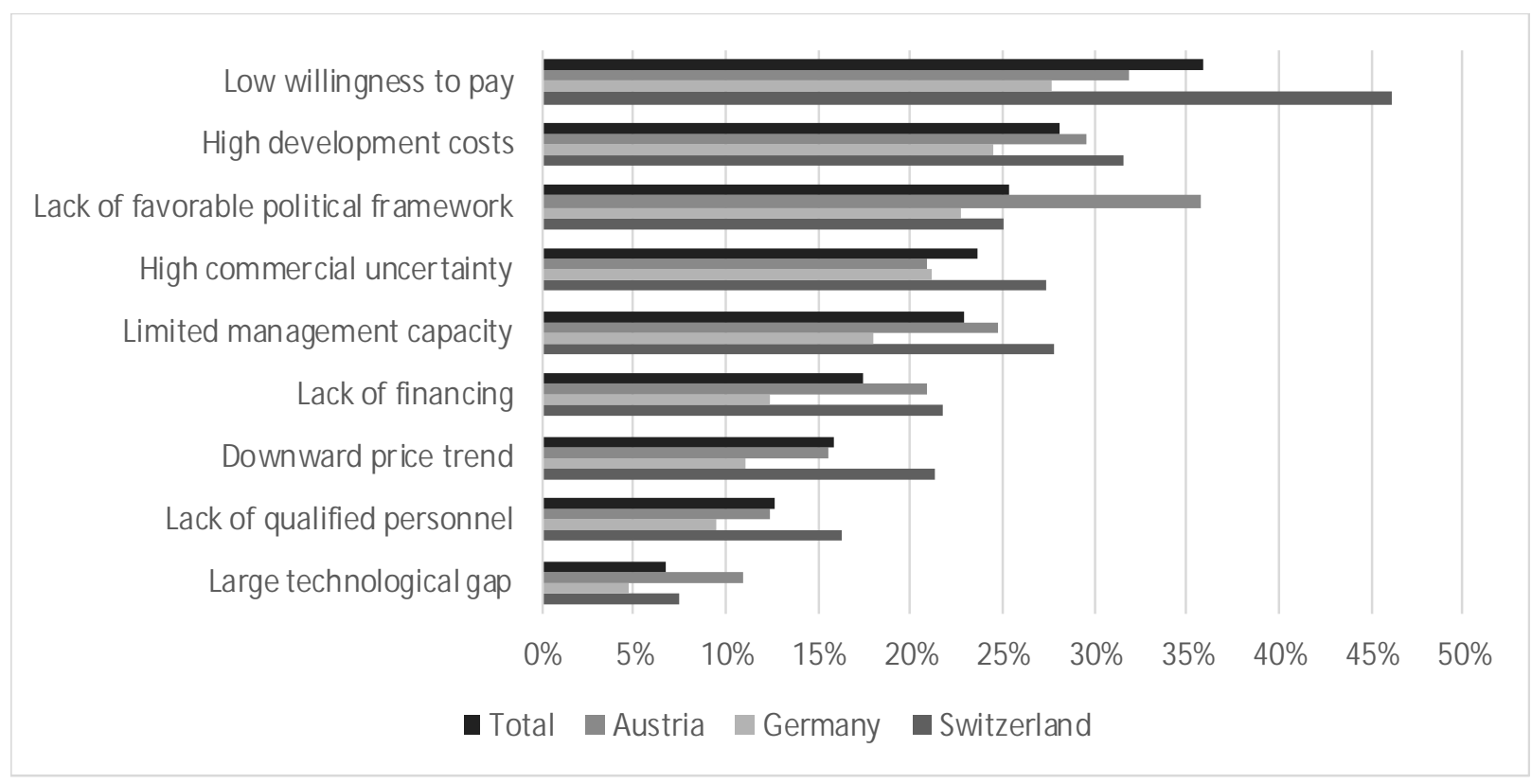

Figure 3: Relevance of perceived green innovation barriers by country (share of firms reporting at least "medium relevance")

\section{Drivers of perceived green innovation barriers}

In Table 1, we analyze the drivers of perceived green innovation barriers and test our hypotheses. In line with hypothesis 1 , we find that green innovation barriers increase with a firm's engagement in innovation activity (see column 1). As it is observed in most studies for general innovation, engagement in green innovation thus increases a firm's awareness of the associated difficulties but does not prevent them from engaging in green innovation activities. 
A significant positive effect is observed regardless of the firms' breath of green innovation activity (see column 2). However, in line with hypothesis 2 , the number of technology fields of a firm's green innovation activities has an inverted U-shaped effect on its perception of green innovation barriers. Firms with green innovation activities in two technology fields have significantly higher perceived innovation barriers than firms with green innovation activities in one technology field, which is probably due to a larger 'revealed effect' of green innovation barriers. However, this positive trend then stops. Enterprises with innovation activities in three to five technology fields have even slightly (but not statistically significant) lower barriers than firms with innovation activities in two technology fields. Hence, as expected, there seems to be a certain learning effect from green innovation activities in different technology fields, which limits or even reduces the (positive) revealed effect of green innovation activity on green innovation barriers.

Not only the breadth of green innovation activities, but also experience in non-green innovation seems to influence a firm's perceived green innovation barriers. In Table 2, we present the same regression as in column 1 of Table 1 separately for companies with different intensities in non-green innovation. As stated in hypothesis 3, non-green innovation activity significantly reduces the (positive) revealed effect of green innovation activity on a firm's perception of green innovation barriers. ${ }^{13}$ However, the fact that the effect of green innovation activity is still statistically significant for firms with a high non-green innovation intensity indicates that nongreen innovation experience cannot fully replace green innovation experience. In Table A.5 in the Appendix, we find that this positive effect of green innovation activity for firms with high nongreen innovation intensity is primarily due to firms that at the same time have relatively narrow green innovation experience. While the sole extension of non-green innovation experience only slightly reduces the (positive) revealed effect of green innovation activity (Table 2), no significant

\footnotetext{
${ }^{13}$ We tested the significance of the moderating effect of non-green innovation intensity by including an interaction term between the firms' non-green innovation intensity and green innovation propensity in our model. As expected this interaction term turned out to be statistically significant negative (results are available on request).
} 
(positive) reveled effect of green innovation activity can be observed for firms that have both broad green innovation experience and intensive non-green innovation experience (Table A.5).

Insert Table 2 about here

Besides the firms' innovation activity, not much significance is observed in our model. Neither firm age, nor export activity, nor firm size show a significant effect. In general, green innovation barriers thus do not seem to be very systematically distributed across firms. This may be because we already selected a very homogeneous group of firms as potential green innovators.

\section{Unobserved heterogeneity}

To further check whether our results are influenced by unobserved heterogeneity, we test the effect of additional control variables in Table 3. In columns 1 and 2 we add controls for the qualification level of the employees and the competition intensity, respectively, which both are typical drivers of a firm's innovation activity. The results, however, indicate that both controls do not affect the firms' perceived innovation barriers.

It could also be argued that the perceived innovation barriers reflect the economic situation of companies. And indeed, we see that companies with low productivity are more affected by green innovation barriers (column 3). Since we cannot clarify the question of the causality of this effect here, it is difficult to interpret this effect. What is relevant to us at this point, however, is that the control for productivity has no influence on our main results.

In columns 4 and 5, we test whether our results are affected by the firms' green process innovation activity and the degree of novelty of their green innovations, respectively. Neither is the case.

In columns 6 to 8 , we finally test the effect of the firms' green policy exposure, which typically is a main driver of green innovation activity (see Horbach 2008). The results indicate that 
the policy measures are positively correlated with the firms' perceived green innovation barriers. This result may be driven by a high correlation between the policy measures and green innovation activity, which makes it hardly possible to disentangle the direct policy effect. The fact that the inclusion of policy measures has no impact on our main outcomes, however, indicates that our results presented before are not influenced by unobserved heterogeneity.

Insert Table 3 about here

\section{Differences by type of innovation barrier}

D'Este et al. (2012) argue in their paper that the effect of innovation activity on innovation barriers may not be the same for different types of barriers. Concretely, they find some evidence that the effect of innovation activity on barriers tend to be positive for "knowledge barriers" and "regulation barriers", which is in line with our overall results, but can be negative for "cost barriers" and, especially, "market barriers". When we conduct a principle component factor analysis, all barriers are grouped into a single factor. This supports our approach to aggregate all barriers into a single measure. Nevertheless, to be able to identify potential differences in the effect of innovation activity on different types of barriers, we present in Table 4 separate probit regressions for all different barriers considered in this study. ${ }^{14}$ The regressions largely confirm our previous findings. First, the effect of green innovation activity is positive for all types of barriers. Hence, awareness indeed seems to be the main driver of this relationship between green innovation activity and green innovation barriers. Second, the relation between breadth of green innovation activity and green innovation barriers tend to be inverted-U shaped.

Insert Table 4 about here

\footnotetext{
${ }^{14}$ To separate the effects for the different groups of green innovation barriers, we also tried to run a multivariate probit regression. Due to the large number of different barriers, the model did not converge.
} 


\section{Discussion and policy implications}

\section{The relevance of different green innovation barriers}

Our descriptive results indicate that green innovation activities are primarily hampered by a "low willingness to pay", "high development costs", "high commercial uncertainty", and "lack of favorable political framework". These findings clearly emphasize the relevance of policy action in this field. On the one hand to directly reduce the lack of a favorable political framework. On the other hand, indirectly, to reduce other green innovation barriers.

To deal with the customers' low willingness to pay for green technologies, governments can implement measures that increase the private payoff to successful green innovation (relative to non-green innovation), i.e. demand-pull policies (Nemet 2009). How such policy can stimulate green innovation in practice can be observed, for example, in the car market. The rising cost of complying with emissions regulations persuade more and more established carmakers to invest in the creation of electric cars (Economist 2017a). Moreover, public incentives directly stimulate the customers' willingness to pay for such electric cars, as can be seen, for example, in Norway, where battery-powered cars and plug-in hybrids together accounted for $29 \%$ of all new car sales in 2016 (Economist 2017b).

If commercial uncertainty is high, firms have less reliable information to plan their investments, which discourages innovation. An example of such instability is the EU Emissions Trading Scheme (EU ETS), which has produced a short-term, volatile and low price for carbon (Helm 2012). Moreover, environmental policy often changes with a change of government or changes in the population's environmental concerns, which for example varies with the business cycle (Kahn and Kotchen 2011). Markets, however, need clear rules and predictable environmental policy. Hence, to stimulate investments in green technologies, policy makers should create a stable political environment. This is even more relevant for small firms, which cannot diversify across 
different technologies, markets, or regions to reduce the problem of uncertainty (Soltmann et al. 2015).

Another main issue are the high development costs for green technologies, which again becomes obvious in the car market. According to a recent article in the Economist (2017a), the development of ten battery-powered models will cost Daimler about $€ 10$ bn by 2025 . And it is not only research and development which affects costs, but also the restructuring of the supply chains and production facilities, which are now optimized to produce cars with internal combustion engines. The total costs of a transition to a supplier of electric cars may be so high that the entire car business of large car manufacturer like VW could make a loss for several years (Economist 2017a). To reduce the private costs of producing green innovation, governments can implement technology-push policies (Nemet 2009), such as tax reductions on green R\&D activities or public R\&D funding (Aghion et al. 2009). Such a stimulating effect of public R\&D on innovation activities is observed, for example, in Klaassen et al. (2005) for wind energy technologies in Denmark, Germany, and United Kingdom. More indirectly, policy could address the problem of high development costs by improving knowledge transfer, e.g. from universities to firms (Mowery and Shane 2002, Siegel et al. 2003), which would lead to a more efficient use of existing knowledge.

Besides potential fields for political intervention, the analysis also indicates which innovation barriers might be of little importance. In general, green innovation does not seem to be heavily hampered by problems of knowledge and financing.

The fact that Swiss firms are more hampered than Austrian and German firms may also reflect the high relevance of policy for green innovation. Compared to Germany and Austria, energy policy is much less dominant in Switzerland (Woerter et al. 2017), which should not only increase the lack of a favorable political framework, but - as discussed above - also indirectly affects other innovation barriers. 
A clear comparison of the barriers between green and non-green innovation would require the same barriers to be surveyed for both samples and that potential innovators can be properly identified for both green and non-green innovation. Unfortunately, this is not possible in our case (see footnote 3). Although the characteristics of green innovation clearly differ from those of nongreen innovation (Section 2.1), the barriers do not seem to differ so much. Overall, the innovation barriers do not appear to be more pronounced for green innovation than for non-green innovation, where also up to $15 \%$ of the firms are heavily affected by certain barriers (Arvanitis et al. 2017). In addition to the fact that some green-specific barriers such as low willingness to pay or political obstacles appear at the top in our study, we also do not observe clear differences between green and non-green innovation barriers regarding the relative importance of the barriers. The two barriers "high costs" and "high market risk" are also among the most relevant barriers to non-green innovation (Arvanitis et al. 2017). The biggest difference seems to exist for the financial barriers. Financial problems are one of the most analyzed barriers to general innovation (Hall 2002), but compared to other barriers, they do not seem to be of great importance for green innovation. Since no data are available for non-green innovation with regard to green-specific barriers, no comparison can be made for these barriers. However, since these barriers directly target specific characteristics of green innovation, such as the low willingness to pay, the high complexity, or the early stage of the technology, it can be assumed that clearer differences would be observed there.

\section{Drivers of green innovation barriers}

First of all, our econometric analysis of the drivers of the firms' perceived green innovation barriers has implications for research. There are many studies investigating the effect of spillovers on innovation activity (e.g., Blundell et al. 1995; Crepon et al. 1998). Some studies also do this for green innovation (Aghion et al. 2016; Stucki and Woerter 2017). However, the focus of these studies is on direct innovation-relevant knowledge. In this study, we were able to show that these knowledge flows are broader and also influence the companies' perceived innovation barriers. 
Knowledge from different technology fields of green innovation as well as knowledge from nongreen innovation helps companies to reduce (or at least limit) the 'revealed effect' of green innovation barriers.

Second, our econometric findings also have implications for policy. By analyzing a broad set of potential drivers of the firms' perceived green innovation barriers, we try to characterize heavily hampered firms, which would then allow policy makers to identify these firms more easily. Unfortunately, such a systematic characterization turned out to be difficult. Although we have tested many potential drivers of the firms' perceived green innovation barriers, only a few of them have proven to be statistically significant. Some systematic differences are observed for the firms' green innovation activities. In general, perceived green innovation barriers seem to be more accentuated for firms with green innovation activity. Hence, to increase the efficiency of policy interventions discussed above, policy interventions should primarily focus on firms, which already have green innovation activity. This is an important political insight, as it would be much more difficult to identify potential green innovators who are not yet active in the green market.

In addition, we also find that among companies with green innovation activities, companies with broad green innovation activities and companies with relatively little experience in non-green innovation perceive the highest green innovation barriers. ${ }^{15}$ Politics can help these companies to reduce their perceived green innovation barriers. In addition, these companies should also try to reduce green innovation barriers themselves, for example by improving their innovation management. Companies with a lot of experience in non-green innovation can benefit from this innovation experience, which means that they generally perceive fewer green innovation barriers than other companies with green innovation activities, even without political intervention.

\footnotetext{
${ }^{15}$ Experience from different fields of green innovation make that the barriers do not increase linearly as the breadth of green innovation activities increases, but barriers do not diminish as a result.
} 


\section{Conclusions}

This paper analyzes the relevance and drivers of perceived green innovation barriers based on representative firm-level data for the three countries Austria, Germany, and Switzerland. Following Rennings (2000), we distinguish between (a) supply-side, (b) demand-side and (c) political factors. All three groups of barriers turn out to be important. The data indicates that green innovation activity is primarily hampered by a "low willingness to pay", "high development costs", "high commercial uncertainty", and "lack of favorable political framework". Problems of knowledge and financing, however, tend to be of low relevance.

Econometric results indicate that it is hardly possible to characterize heavily hampered firms. The only exception is the firms' green innovation activities, which is positively correlated with perceived green innovation barriers. Hence, green innovation activity increases a firm's awareness of innovation barriers, but the barriers do not prevent them from engaging in innovation activities. In addition, we find that knowledge spillover exist with regard to green innovation barriers. Companies with green innovation activities in multiple technology fields can benefit from this broad experience, which means that these companies perceive on average (lightly) fewer green innovation barriers than companies with more narrow green innovation activities. The same applies to knowledge from non-green innovation; of the companies with green innovation activities, companies with a lot of non-green innovation experience tend to perceive fewer green innovation barriers than companies with comparatively little non-green experience.

\section{References}

Agarwal, R., \& Bayus, B. L. (2002). The market evolution and sales takeoff of product innovations. Management Science, 48(8), 1024-1041.

Aghion, P., Dechezleprêtre, A., Hemous, D., Martin, R., \& Van Reenen, J. (2016). Carbon taxes, path dependency, and directed technical change: Evidence from the auto industry. Journal of Political Economy, 124(1), 1-51.

Aghion, P., Veugelers, R., \& Serre, C. (2009). Cold start for the green innovation machine. Bruegel Policy Contribution, 2009/12, Bruegel, Brussels

Arrow, K. A. (1962). Economic welfare and the allocation of resources to invention. In: Mirowski P, Sent EM (eds) Science bought and sold. The University of Chicago Press, Chicago, 2002, pp 165-180 
Arvanitis, S., \& Ley, M. (2010). Generierung und Übernahme von Energietechnologien und energiepolitische Förderung in der Schweiz (No. 18). KOF Studien.

Arvanitis, S., Peneder, M., Rammer, C., Spescha, A., Stucki, T., \& Woerter, M. (2016). Creation and Adoption of Energy-related Innovations-the Main Facts, KOF Studies, Vol. 77.

Arvanitis, S., Seliger, F., Spescha, A., Stucki, T., \& Wörter, M. (2017). Die Entwicklung der Innovationsaktivitäten in der Schweizer Wirtschaft 1997-2014: Studie im Auftrag des Staatssekretariats für Wirtschaft (SECO). KOF Studies, 88.

Baldwin, J., \& Lin, Z. (2002). Impediments to advanced technology adoption for Canadian manufacturers. Research policy, 31(1), 1-18.

Barney, J. (1991). Special theory forum the resource-based model of the firm: origins, implications, and prospects. Journal of management, 17(1), 97-98.

Barney, J., Wright, M., \& Ketchen Jr, D. J. (2001). The resource-based view of the firm: Ten years after 1991. Journal of management, 27(6), 625-641.

Berrone, P., Fosfuri, A., Gelabert, L., \& Gomez-Mejia, L. R. (2013). Necessity as the mother of 'green'inventions: Institutional pressures and environmental innovations. Strategic Management Journal, 34(8), 891-909.

Berry, D. (2009). Innovation and the price of wind energy in the US. Energy Policy, 37(11), 44934499.

Blanchard, P., Huiban, J. P., Musolesi, A., \& Sevestre, P. (2013). Where there is a will, there is a way? Assessing the impact of obstacles to innovation. Industrial and Corporate Change, 22(3), 679-710.

Blundell, R., Griffith, R., \& Van Reenen, J. (1995). Dynamic count data models of technological innovation. The Economic Journal, 333-344.

Cainelli, G., De Marchi, V., \& Grandinetti, R. (2015). Does the development of environmental innovation require different resources? Evidence from Spanish manufacturing firms. Journal of Cleaner Production, 94, 211-220.

Canepa, A., \& Stoneman, P. (2007). Financial constraints to innovation in the UK: evidence from CIS2 and CIS3. Oxford economic papers, 60(4), 711-730.

Cohen, W. M. (2010). Fifty years of empirical studies of innovative activity and performance. In Handbook of the Economics of Innovation (Vol. 1, pp. 129-213). Elsevier, North-Holland.

Consoli, D., Marin, G., Marzucchi, A., \& Vona, F. (2016). Do green jobs differ from non-green jobs in terms of skills and human capital?. Research Policy, 45(5), 1046-1060.

Costa-Campi, M. T., Duch-Brown, N., \& Garcia-Quevedo, J. (2014). R\&D drivers and obstacles to innovation in the energy industry. Energy Economics, 46, 20-30.

Costantini, V., Crespi, F., Martini, C., \& Pennacchio, L. (2015). Demand-pull and technology-push public support for eco-innovation: The case of the biofuels sector. Research Policy, 44(3), 577595.

Crepon, B., Duguet, M. and Mairesse, J. (1998). Research, Innovation, and Productivity: an Econometric Analysis at the Firm Level. Economics of Innovation and New Technology 7(2): 115-158.

Cuerva, M. C., Triguero-Cano, Á., \& Córcoles, D. (2014). Drivers of green and non-green innovation: empirical evidence in Low-Tech SMEs. Journal of Cleaner Production, 68, 104113.

Danneels, E. (2002). The dynamics of product innovation and firm competences. Strategic management journal, 23(12), 1095-1121.

D’Este, P., Iammarino, S., Savona, M., \& von Tunzelmann, N. (2012). What hampers innovation? Revealed barriers versus deterring barriers. Research policy, 41(2), 482-488.

Dutton, J. M., \& Thomas, A. (1984). Treating progress functions as a managerial opportunity. Academy of management review, 9(2), 235-247.

Economist (2017a). Volts wagons - Electric cars are set to arrive far more speedily than anticipated, 18 February.

Economist (2017b). Northern light - Sales of green vehicles are booming in Norway, 18 February. 
Galia, F., \& Legros, D. (2004). Complementarities between obstacles to innovation: evidence from France. Research policy, 33(8), 1185-1199.

Ghisetti, C., \& Rennings, K. (2014). Environmental innovations and profitability: how does it pay to be green? An empirical analysis on the German innovation survey. Journal of Cleaner production, 75, 106-117.

Ghisetti, C., Mancinelli, S., Mazzanti, M., \& Zoli, M. (2017). Financial barriers and environmental innovations: evidence from EU manufacturing firms. Climate Policy, 17(sup1), S131-S147.

Hall, B. H. (2002). The financing of research and development. Oxford review of economic policy, $18(1), 35-51$.

Hall, B. H., \& Helmers, C. (2013). Innovation and diffusion of clean/green technology: Can patent commons help?. Journal of Environmental Economics and Management, 66(1), 33-51.

Helm, D. (2012). Climate policy: The Kyoto approach has failed. Nature, 491(7426), 663-665.

Henderson, R., \& Cockburn, I. (1996). Scale, scope, and spillovers: the determinants of research productivity in drug discovery. The Rand journal of economics, 32-59.

Horbach, J. (2008). Determinants of environmental innovation-New evidence from German panel data sources. Research policy, 37(1), 163-173.

Hottenrott, H., \& Peters, B. (2012). Innovative capability and financing constraints for innovation: More money, more innovation?. Review of Economics and Statistics, 94(4), 1126-1142.

Hyytinen, A., \& Toivanen, O. (2005). Do financial constraints hold back innovation and growth?: Evidence on the role of public policy. Research Policy, 34(9), 1385-1403.

Iammarino, S., Sanna-Randaccio, F., \& Savona, M. (2009). The perception of obstacles to innovation. Foreign multinationals and domestic firms in Italy. Revue d'économie industrielle, (125), 75-104.

IPCC (2014). Climate Change 2014: Synthesis Report. Contribution of Working Groups I, II and III to the Fifth Assessment Report of the Intergovernmental Panel on Climate Change [Core Writing Team, R.K. Pachauri and L.A. Meyer (eds.)]. IPCC, Geneva, Switzerland, 151 pp.

Jaffe, A. B., Newell, R. G., \& Stavins, R. N. (2005). A tale of two market failures: Technology and environmental policy. Ecological economics, 54(2-3), 164-174.

Kahn, M. E., \& Kotchen, M. J. (2011). Business cycle effects on concern about climate change: the chilling effect of recession. Climate Change Economics, 2(03), 257-273.

Klaassen, G., Miketa, A., Larsen, K., \& Sundqvist, T. (2005). The impact of R\&D on innovation for wind energy in Denmark, Germany and the United Kingdom. Ecological economics, 54(2), 227-240.

Ley, M., Stucki, T., \& Woerter, M. (2016). The impact of energy prices on green innovation. The Energy Journal, 37(1), 41-75.

Marin, G. (2014). Do eco-innovations harm productivity growth through crowding out? Results of an extended CDM model for Italy. Research Policy, 43(2), 301-317.

Marin, G., Marzucchi, A., \& Zoboli, R. (2015). SMEs and barriers to Eco-innovation in the EU: exploring different firm profiles. Journal of Evolutionary Economics, 25(3), 671-705.

Mohnen, P., Palm, F. C., Van Der Loeff, S. S., \& Tiwari, A. (2008). Financial constraints and other obstacles: are they a threat to innovation activity? De Economist, 156(2), 201-214.

Mohnen, P., \& Röller, L. H. (2005). Complementarities in innovation policy. European Economic Review, 49(6), 1431-1450.

Mohnen, P., \& Rosa, J. (2001). Les obstacles à l'innovation dans les industries de services au Canada. L'Actualité économique, 77(2), 231-254.

Mowery, D. C., \& Shane, S. (2002). Introduction to the special issue on university entrepreneurship and technology transfer. Management Science, 48(1), v-ix.

Nemet, G. F. (2009). Demand-pull, technology-push, and government-led incentives for nonincremental technical change. Research Policy, 38(5), 700-709.

Noci, G., \& Verganti, R. (1999). Managing 'green'product innovation in small firms. R\&d Management, 29(1), 3-15.

OECD (2012): Indicators of Environmental Technologies (ENV-Tech Indicators), OECD, Paris. 
Pellegrino, G., \& Savona, M. (2017). No money, no honey? Financial versus knowledge and demand constraints on innovation. Research Policy, 46(2), 510-521.

Popp, D., Newell, R. G., \& Jaffe, A. B. (2010). Energy, the environment, and technological change. In: Hall, B. H., Rosenberg, N. (eds) Handbook of the economics of innovation, (Vol. 2, pp. 873-937). Elsevier, North-Holand.

Porter, M. E., \& Van der Linde, C. (1995). Toward a new conception of the environmentcompetitiveness relationship. Journal of economic perspectives, 9(4), 97-118.

Pruett, M., \& Thomas, H. (2008). Experience-based learning in innovation and production. R\&D Management, 38(2), 141-153.

Reichelstein, S., \& Yorston, M. (2013). The prospects for cost competitive solar PV power. Energy Policy, 55, 117-127.

Rennings, K. (2000). Redefining innovation-eco-innovation research and the contribution from ecological economics. Ecological economics, 32(2), 319-332.

Rexhäuser, S., \& Rammer, C. (2014). Environmental innovations and firm profitability: unmasking the Porter hypothesis. Environmental and Resource Economics, 57(1), 145-167.

Rubashkina, Y., Galeotti, M., \& Verdolini, E. (2015). Environmental regulation and competitiveness: Empirical evidence on the Porter Hypothesis from European manufacturing sectors. Energy Policy, 83, 288-300.

Savignac, F. (2008). Impact of financial constraints on innovation: What can be learned from a direct measure?. Econ. Innov. New Techn., 17(6), 553-569.

Shrivastava, P. (1995). Environmental technologies and competitive advantage. Strategic management journal, 16(S1), 183-200.

Siegel, D. S., Waldman, D. A., Atwater, L. E., \& Link, A. N. (2003). Commercial knowledge transfers from universities to firms: improving the effectiveness of university-industry collaboration. The Journal of High Technology Management Research, 14(1), 111-133.

Soltmann, C., Stucki, T., \& Woerter, M. (2015). The Impact of Environmentally Friendly Innovations on Value Added. Environmental and Resource Economics, 62(3), 457-479.

Souto, J. E., \& Rodriguez, A. (2015). The problems of environmentally involved firms: innovation obstacles and essential issues in the achievement of environmental innovation. Journal of Cleaner Production, 101, 49-58.

Stucki, T., \& Woerter, M. (2017). Green Inventions: Is Wait-and-see a Reasonable Option?. The Energy Journal, 38(4).

Stucki, T., \& Woerter, M. (2018). Competitive Pressure and Diversification into Green R\&D. Review of Industrial Organization, 1-25.

Stucki, T., Woerter, M., Arvanitis, S., Peneder, M., \& Rammer, C. (2018). How different policy instruments affect green product innovation: A differentiated perspective. Energy Policy, 114, 245-261.

Stucki, T. (2019). Which firms benefit from investments in green energy technologies?-The effect of energy costs. Research Policy, 48(3), 546-555.

Van Leeuwen, G., \& Mohnen, P. (2017). Revisiting the Porter hypothesis: an empirical analysis of green innovation for the Netherlands. Economics of Innovation and New Technology, 26(12), 63-77.

Woerter, M., Stucki, T., Arvanitis, S., Rammer, C., \& Peneder, M. (2017). The adoption of green energy technologies: The role of policies in Austria, Germany, and Switzerland. International Journal of Green Energy, 14(14), 1192-1208.

Wooldridge, J. M. (2002). Introductory Econometrics e a Modern Approach, second ed. SouthWestern.

Wright, T. P. (1936). Factors affecting the cost of airplanes. Journal of the aeronautical sciences, $3(4), 122-128$.

Yelle, L. E. (1979). The learning curve: Historical review and comprehensive survey. Decision sciences, 10(2), 302-328. 
Table 1: Main results (based on fractional logit regressions)

(1) (2)

Breadth of green innovation barriers

\begin{tabular}{lcc}
\hline Green innovation propensity & $\begin{array}{c}0.459^{* * *} \\
(0.115)\end{array}$ \\
1 green innovation field & & $0.259^{*}$ \\
& & $(0.145)$ \\
2 green innovation fields & & $0.787^{* * *}$ \\
& & $(0.206)$ \\
3-5 green innovation fields & & $0.547^{* *}$ \\
& & $(0.233)$ \\
Firm age & 0.035 & 0.028 \\
& $(0.070)$ & $(0.070)$ \\
Export activity & 0.093 & 0.077 \\
& $(0.132)$ & $(0.132)$ \\
Foreign owned & -0.049 & -0.041 \\
& $(0.161)$ & $(0.162)$ \\
Firm size & -0.032 & -0.032 \\
& $(0.038)$ & $(0.038)$ \\
Swiss firm & 0.204 & 0.194 \\
& $(0.167)$ & $(0.167)$ \\
German firm & $-0.345^{* *}$ & $-0.352^{* *}$ \\
& $(0.156)$ & $(0.157)$ \\
Constant & -1.042 & -0.997 \\
& $(1.081)$ & $(1.082)$ \\
Industry controls & yes & yes \\
\hline $\mathrm{N}$ & 909 & 909 \\
Root mse & 2.168 & 2.171 \\
\hline
\end{tabular}

Notes: see Table A.2 in the Appendix for the variable definitions; standard errors are in brackets under the coefficients; $* * *, * *, *$, denote statistical significance at the $1 \%, 5 \%$ and $10 \%$ test level, respectively. 
Table 2: Subsample analysis (based on fractional logit regressions)

(1)

(2)

(3)

Sample: No non-green Low non-green High non-green innovation activities innovation intensity innovation intensity

Breadth of green innovation barriers

\begin{tabular}{lccc}
\hline Green innovation propensity & $1.431^{* * *}$ & $0.566^{* * *}$ & $0.409^{*}$ \\
Firm age & $(0.434)$ & $(0.200)$ & $(0.223)$ \\
& -0.139 & -0.096 & $0.261^{*}$ \\
Export activity & $(0.142)$ & $(0.140)$ & $(0.137)$ \\
Foreign owned & 0.177 & -0.147 & $0.575 *$ \\
& $(0.251)$ & $(0.257)$ & $(0.301)$ \\
Firm size & 0.018 & 0.337 & -0.401 \\
& $(0.400)$ & $(0.329)$ & $(0.272)$ \\
Swiss firm & 0.013 & -0.045 & -0.103 \\
& $(0.083)$ & $(0.070)$ & $(0.075)$ \\
German firm & 0.450 & 0.103 & 0.345 \\
& $(0.479)$ & $(0.354)$ & $(0.277)$ \\
Constant & -0.663 & $-0.637 *$ & 0.080 \\
& $(0.450)$ & $(0.343)$ & $(0.272)$ \\
Industry controls & $-1.439 * *$ & $-19.775 * * *$ & -1.473 \\
\hline $\mathrm{N}$ & $(0.664)$ & $(1.562)$ & $(1.570)$ \\
Root mse & yes & yes & yes \\
\hline
\end{tabular}

Notes: see Table A.2 in the Appendix for the variable definitions; standard errors are in brackets under the coefficients; $* * *, * *, *$, denote statistical significance at the $1 \%, 5 \%$ and $10 \%$ test level, respectively. Firms are divided into low and high non-green innovation intensive firms based on the median firm's non-green innovation sales per capita, which is $322^{\prime} 341 €$. 
Table 3: Testing additional controls (based on fractional logit regressions)
(1)
(2)
(3)
(4)
(5)
(6)
(7)
(8)

\begin{tabular}{|c|c|c|c|c|c|c|c|c|}
\hline \multirow[t]{2}{*}{1 green innovation field } & $0.261^{*}$ & $0.259 *$ & 0.221 & $0.268 *$ & 0.162 & $0.280 *$ & $0.278 *$ & 0.220 \\
\hline & $(0.145)$ & $(0.145)$ & $(0.146)$ & $(0.147)$ & $(0.163)$ & $(0.146)$ & $(0.145)$ & $(0.145)$ \\
\hline \multirow[t]{2}{*}{2 green innovation fields } & $0.790 * * *$ & $0.781 * * *$ & $0.776^{* * *}$ & $0.743 * * *$ & $0.696 * * *$ & $0.779 * * *$ & $0.751^{* * *}$ & $0.736 * * *$ \\
\hline & $(0.206)$ & $(0.206)$ & $(0.207)$ & $(0.210)$ & $(0.218)$ & $(0.207)$ & $(0.206)$ & $(0.206)$ \\
\hline \multirow[t]{2}{*}{ 3-5 green innovation fields } & $0.550^{* *}$ & $0.533^{* *}$ & $0.533^{* *}$ & $0.527^{* *}$ & 0.403 & $0.529 * *$ & $0.523^{* *}$ & $0.466^{* *}$ \\
\hline & $(0.234)$ & $(0.234)$ & $(0.234)$ & $(0.238)$ & $(0.251)$ & $(0.234)$ & $(0.233)$ & $(0.235)$ \\
\hline \multirow[t]{2}{*}{ Firm age } & 0.027 & 0.030 & 0.038 & 0.018 & 0.032 & 0.008 & 0.065 & 0.030 \\
\hline & $(0.070)$ & $(0.070)$ & $(0.071)$ & $(0.071)$ & $(0.070)$ & $(0.071)$ & $(0.070)$ & $(0.070)$ \\
\hline \multirow[t]{2}{*}{ Export activity } & 0.083 & 0.078 & 0.080 & 0.086 & 0.087 & 0.097 & 0.075 & 0.091 \\
\hline & $(0.135)$ & $(0.133)$ & $(0.133)$ & $(0.134)$ & $(0.132)$ & $(0.133)$ & $(0.132)$ & $(0.132)$ \\
\hline \multirow[t]{2}{*}{ Foreign owned } & -0.039 & -0.030 & 0.019 & -0.040 & -0.043 & -0.035 & -0.008 & -0.015 \\
\hline & $(0.162)$ & $(0.162)$ & $(0.164)$ & $(0.163)$ & $(0.162)$ & $(0.162)$ & $(0.162)$ & $(0.162)$ \\
\hline \multirow[t]{2}{*}{ Firm size } & -0.031 & -0.029 & -0.008 & -0.028 & -0.036 & -0.038 & $-0.065 *$ & -0.036 \\
\hline & $(0.038)$ & $(0.038)$ & $(0.039)$ & $(0.039)$ & $(0.038)$ & $(0.038)$ & $(0.038)$ & $(0.038)$ \\
\hline \multirow[t]{2}{*}{ Swiss firm } & 0.197 & 0.182 & 0.269 & 0.192 & 0.198 & 0.187 & 0.102 & 0.216 \\
\hline & $(0.168)$ & $(0.168)$ & $(0.173)$ & $(0.169)$ & $(0.167)$ & $(0.168)$ & $(0.169)$ & $(0.167)$ \\
\hline \multirow[t]{2}{*}{ German firm } & $-0.343 * *$ & $-0.354 * *$ & $-0.384 * *$ & $-0.349 * *$ & $-0.354 * *$ & $-0.389 * *$ & $-0.381 * *$ & $-0.353^{* *}$ \\
\hline & $(0.161)$ & $(0.157)$ & $(0.158)$ & $(0.158)$ & $(0.157)$ & $(0.158)$ & $(0.157)$ & $(0.156)$ \\
\hline \multirow[t]{2}{*}{ Share of high qualified employees } & -0.012 & & & & & & & \\
\hline & $(0.051)$ & & & & & & & \\
\hline \multirow[t]{2}{*}{ Competition intensity } & & 0.038 & & & & & & \\
\hline & & $(0.039)$ & & & & & & \\
\hline \multirow[t]{2}{*}{ Firm productivity } & & & $-0.253^{* *}$ & & & & & \\
\hline & & & $(0.105)$ & & & & & \\
\hline \multirow[t]{2}{*}{ Green process innovation } & & & & 0.005 & & & & \\
\hline & & & & $(0.017)$ & & & & \\
\hline \multirow[t]{2}{*}{ New to the market innovation } & & & & & 0.250 & & & \\
\hline & & & & & $(0.187)$ & & & \\
\hline \multirow[t]{2}{*}{ Taxes } & & & & & & $0.279 * * *$ & & \\
\hline & & & & & & $(0.104)$ & & \\
\hline \multirow[t]{2}{*}{ Regulations } & & & & & & & $0.495^{* * *}$ & \\
\hline & & & & & & & $(0.104)$ & \\
\hline \multirow[t]{2}{*}{ Subsidies } & & & & & & & & $0.286 * * *$ \\
\hline & & & & & & & & $(0.102)$ \\
\hline \multirow[t]{2}{*}{ Constant } & -0.961 & -1.198 & 1.841 & -0.987 & -1.009 & -1.189 & -1.450 & -1.054 \\
\hline & $(1.094)$ & $(1.102)$ & $(1.590)$ & $(1.082)$ & $(1.083)$ & (1.088) & $(1.082)$ & $(1.082)$ \\
\hline Industry controls & yes & yes & yes & yes & yes & yes & yes & yes \\
\hline $\mathrm{N}$ & 909 & 909 & 905 & 890 & 909 & 909 & 909 & 909 \\
\hline Root mse & 2.173 & 2.175 & 2.190 & 2.163 & 2.172 & 2.187 & 2.168 & 2.166 \\
\hline
\end{tabular}

Notes: see Table A.2 in the Appendix for the variable definitions; standard errors are in brackets under the coefficients; $* * *, * *, *$ denote statistical significance at the $1 \%, 5 \%$ and $10 \%$ test level, respectively. 
Table 4: Compare different types of barriers (based on separate probit regressions)

\begin{tabular}{|c|c|c|c|c|c|c|c|c|c|}
\hline & (1) & (2) & (3) & (4) & (5) & (6) & (7) & (8) & (9) \\
\hline & $\begin{array}{c}\text { High } \\
\text { development } \\
\text { costs }\end{array}$ & $\begin{array}{c}\text { Lack of } \\
\text { qualified } \\
\text { personnel }\end{array}$ & $\begin{array}{l}\text { Limited } \\
\text { management } \\
\text { capacity }\end{array}$ & $\begin{array}{c}\text { Large } \\
\text { technological } \\
\text { gap }\end{array}$ & $\begin{array}{l}\text { Lack of } \\
\text { financing }\end{array}$ & $\begin{array}{l}\text { Lack of } \\
\text { favorable } \\
\text { political } \\
\text { framework }\end{array}$ & $\begin{array}{c}\text { Low } \\
\text { willingness } \\
\text { to pay }\end{array}$ & $\begin{array}{c}\text { High } \\
\text { commercial } \\
\text { uncertainty }\end{array}$ & $\begin{array}{c}\text { Downward } \\
\text { price } \\
\text { trend }\end{array}$ \\
\hline \multirow[t]{2}{*}{1 green innovation field } & 0.116 & 0.190 & -0.045 & 0.250 & 0.098 & 0.186 & $0.261^{* *}$ & 0.003 & 0.134 \\
\hline & $(0.130)$ & $(0.157)$ & $(0.140)$ & $(0.183)$ & $(0.152)$ & $(0.135)$ & $(0.126)$ & $(0.139)$ & $(0.146)$ \\
\hline \multirow[t]{2}{*}{2 green innovation fields } & $0.500 * * *$ & $0.424 * *$ & $0.323^{*}$ & 0.248 & $0.631 * * *$ & $0.652 * * *$ & $0.567 * * *$ & $0.607 * * *$ & 0.051 \\
\hline & $(0.180)$ & $(0.211)$ & $(0.186)$ & $(0.257)$ & $(0.197)$ & $(0.179)$ & $(0.178)$ & $(0.181)$ & $(0.219)$ \\
\hline \multirow[t]{2}{*}{ 3-5 green innovation fields } & $0.495^{* *}$ & 0.269 & 0.086 & 0.121 & 0.352 & $0.495^{* *}$ & $0.412^{* *}$ & 0.206 & 0.216 \\
\hline & $(0.203)$ & $(0.245)$ & $(0.219)$ & $(0.290)$ & $(0.225)$ & $(0.204)$ & $(0.201)$ & $(0.213)$ & $(0.229)$ \\
\hline \multirow[t]{2}{*}{ Firm age } & -0.029 & 0.097 & 0.072 & 0.140 & -0.055 & -0.036 & 0.010 & -0.005 & 0.107 \\
\hline & $(0.064)$ & $(0.081)$ & $(0.068)$ & $(0.099)$ & $(0.074)$ & $(0.066)$ & $(0.063)$ & $(0.068)$ & $(0.077)$ \\
\hline \multirow[t]{2}{*}{ Export activity } & 0.007 & -0.206 & 0.176 & -0.218 & 0.110 & 0.107 & 0.115 & 0.018 & -0.139 \\
\hline & $(0.123)$ & $(0.147)$ & $(0.129)$ & $(0.176)$ & $(0.137)$ & $(0.125)$ & $(0.119)$ & $(0.126)$ & $(0.142)$ \\
\hline \multirow[t]{2}{*}{ Foreign owned } & -0.051 & -0.162 & 0.015 & -0.081 & 0.109 & -0.073 & 0.180 & 0.000 & -0.117 \\
\hline & $(0.147)$ & $(0.188)$ & $(0.151)$ & $(0.217)$ & $(0.165)$ & $(0.152)$ & $(0.142)$ & $(0.155)$ & $(0.169)$ \\
\hline \multirow[t]{2}{*}{ Firm size } & 0.032 & -0.061 & -0.039 & -0.001 & $-0.162 * * *$ & 0.005 & -0.003 & 0.020 & -0.028 \\
\hline & $(0.035)$ & $(0.043)$ & $(0.037)$ & $(0.050)$ & $(0.042)$ & $(0.035)$ & $(0.034)$ & $(0.036)$ & $(0.040)$ \\
\hline \multirow[t]{2}{*}{ Swiss firm } & 0.075 & 0.115 & 0.183 & -0.299 & 0.064 & $-0.329 * *$ & $0.464 * * *$ & 0.184 & 0.122 \\
\hline & $(0.151)$ & $(0.184)$ & $(0.155)$ & $(0.205)$ & $(0.165)$ & $(0.151)$ & $(0.149)$ & $(0.160)$ & $(0.174)$ \\
\hline \multirow[t]{2}{*}{ German firm } & -0.167 & -0.243 & -0.235 & $-0.575 * * *$ & $-0.438 * * *$ & $-0.340 * *$ & -0.012 & 0.013 & -0.208 \\
\hline & $(0.143)$ & $(0.179)$ & $(0.149)$ & $(0.199)$ & $(0.159)$ & $(0.141)$ & $(0.142)$ & $(0.152)$ & $(0.169)$ \\
\hline \multirow[t]{2}{*}{ Constant } & 0.166 & -5.442 & -5.425 & $-1.975^{* * *}$ & -4.441 & -4.307 & -0.125 & -4.772 & -4.598 \\
\hline & $(0.922)$ & (142.873) & (139.742) & $(0.507)$ & (111.880) & $(110.724)$ & $(0.925)$ & $(130.952)$ & $(129.897)$ \\
\hline Industry controls & yes & yes & yes & yes & yes & yes & yes & yes & yes \\
\hline $\mathrm{N}$ & 909 & 909 & 909 & 909 & 909 & 909 & 909 & 909 & 909 \\
\hline pseudo R2 & 0.03 & 0.05 & 0.04 & 0.05 & 0.07 & 0.05 & 0.06 & 0.04 & 0.05 \\
\hline
\end{tabular}

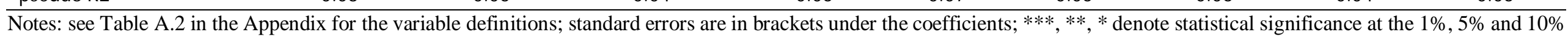
test level, respectively. 
Table A.1: Relevant questions in the survey

Q4.1. Has your company introduced at least one of the following energy technologies for use in your own company in the period $2012-2014$ (yes/no):

a) Energy-saving technologies in the field:

- Production (e.g., electrical machines and drive systems),

- Information and communication technology (ICT, e.g., energy-saving servers)

- Transport (e.g., engines of motor vehicles, electric cars)

- Building technology (e.g., temperature isolation, lighting, heating, air ventilation)

- Other energy-saving technologies/procedures (e.g., more efficient gas turbines, cogeneration of heat and power), which are ...

b) Technologies for the use of energy from renewable sources (e.g., solar systems, wind power plants, hydroelectric power plants).

$\mathrm{Q}$ 4.2. Proportion of investments for the introduction of these technologies in your company's total investments on average for the years 2012 to 2014.

Q. 5.6. Did the following factors in the period from 2012 to 2014 lead to the abandonment of the development and market launch of products/services in the area of new green energy technologies or significantly hamper them? (four-level ordinary variables: level 1: 'not relevant', level 2: 'low relevance', level 3: 'medium relevance', level 4: 'high relevance')

- Our products/offers are not suitable for this purpose

- High development costs

- Development gap too big against the competition

- Falling technology price trend

- Customers' low willingness to pay

- Lack of sources of financing

- Excessive economic risk

- Lack of qualified personnel

- Management capacities tied elsewhere

- Lack of political framework (e.g., insufficient funding, lack of legal certainty) 
Table A.2: Variable definition

Variable

Definition/measurement

Dependent variables

Breadth of green innovation barriers

Fraction of green innovation barriers with at least low relevance (survey includes information on 9 different barriers: (a) high development costs, (b) lack of qualified personnel, (c) limited management capacity, (d) large technological gap, (e) lack of financing, (f) lack of favorable political framew ork, (g) low willingness to pay, (h) high commercial uncertainty, (i) downward technology price trend; four-level ordinary variables: level 1: 'not relevant', level 2: 'low relevance', level 3: 'medium relevance', level 4: 'high relevance')

Fraction of green innovation barriers with high relevance

Depth of green innovation barriers

(9 barriers included in the survey; four-level ordinary variables: level 1: 'not relevant', level 2: 'low relevance', level 3: 'medium relevance', level 4: 'high relevance')

\section{Independent variables}

Green innovation propensity

1 green innovation field;

2 green innovation fields;

3-5 green innovation fields

Non-green innovation intensity

Firm age

Export activity

Foreign owned

Firm size

Swiss firm; German firm

Share of high qualified employees

Competition intensity

Firm productivity

Green process innovation

New to the market innovation

Taxes

Regulations

Subsidies

Industry controls
Firm created green energy products or services yes/ no

Number of technology fields in which a firm has green innovation activities

(reference: no green innovation activity; technology fields of green innovation: (a) production (e.g., electrical machines and drive systems), (b) information and communication technology (e.g., energy-saving servers), (c) transport (e.g., engines of motor vehicles, electric cars), (d) building technology (e.g., temperature isolation, lighting, heating, air ventilation), (e) green energy generation (e.g., photovoltaics, wind power, hydro-electric power stations))

Non-green R\&D expenditures per capita, In

Firm age in years, In

Firm has export activities yes/no

Firm is owned by a foreign company yes/no

Number of employees measured in full-time equivalents, In

The firm's country of origin (reference country: Austria)

Share of employees with a tertiary-level degree, In

Number of competitors on the firm's domestic and foreign prime market (five-level ordinal variable: level 1: 'up to 5' (reference category), level 2: ' 6 to 10 ', level 3: '11 to 15 ', level 4: '16 to 50', level 5: 'more than 50')

Value added per capita, In

Gross investments in green energy products/ services (for the use within the firm) per employee, In

Green product innovations were new to the market yes/no

Firm-specific relevance of energy related taxes

(three-level ordinary variable; level 1: 'not relevant'; level 3: 'high relevance') Firm-specific relevance of energy related regulations and standards (three-level ordinary variable; level 1: 'not relevant'; level 3: 'high relevance') Firm-specific relevance of energy related public subsidies (three-level ordinary variable; level 1: 'not relevant'; level 3: 'high relevance') Controls for industry affiliation based on NACE two-digit codes 
Table A.3: Descriptive statistics

\begin{tabular}{lcccc} 
Variable & Mean & Std. Dev. & M in & Max \\
\hline Breadth of green innovation barriers & 0.21 & 0.23 & 0 & 1 \\
Green innovation propensity & 0.28 & 0.45 & 0 & 1 \\
1 green innovation field & 0.15 & 0.36 & 0 & 1 \\
2 green innovation fields & 0.06 & 0.24 & 0 & 1 \\
3-5 green innovation fields & 0.05 & 0.21 & 0 & 1 \\
Firm age & 48.17 & 40.37 & 2 & 260 \\
Export activity & 0.69 & 0.46 & 0 & 1 \\
Foreign owned & 0.12 & 0.33 & 0 & 1 \\
Firm size & 313.50 & 2559.49 & 1 & 71400 \\
\hline Notes: N=909; based on same sample as main model in Table 1. &
\end{tabular}


Table A.4: Correlation matrix

\begin{tabular}{|c|c|c|c|c|c|c|c|c|}
\hline & $\begin{array}{l}\text { Breadth of green } \\
\text { innovation barriers }\end{array}$ & $\begin{array}{l}\text { Green innovation } \\
\text { propensity }\end{array}$ & $\begin{array}{l}1 \text { green innovation } \\
\text { field }\end{array}$ & $\begin{array}{l}2 \text { green innovation } \\
\text { fields }\end{array}$ & $\begin{array}{c}\text { 3-5 green } \\
\text { innovation fields }\end{array}$ & Firm age & Export activity & Foreign owned \\
\hline
\end{tabular}

Notes: $\mathrm{N}=909$; based on same sample as main model in Table 1. 
Table A.5: Splitting the effect of green innovation activity for firms with high non-green innovation intensity

Sample: $\begin{gathered}\text { High non-green } \\ \text { innovation intensity }\end{gathered}$

\begin{tabular}{lc} 
& Breadth of green innovation barriers \\
\hline 1 green innovation field & $0.478^{*}$ \\
& $(0.278)$ \\
2 green innovation fields & 0.400 \\
& $(0.441)$ \\
$3-5$ green innovation fields & 0.216 \\
& $(0.432)$ \\
Firm age & $0.276^{* *}$ \\
& $(0.138)$ \\
Export activity & $0.562^{*}$ \\
& $(0.303)$ \\
Foreign owned & -0.422 \\
Firm size & $(0.277)$ \\
& -0.105 \\
Swiss firm & $(0.076)$ \\
German firm & 0.314 \\
Constant & $(0.278)$ \\
& 0.099 \\
Industry controls & $(0.274)$ \\
Noot mse & -1.522 \\
\hline & $(1.576)$ \\
& yes \\
\hline
\end{tabular}

Notes: see Table A.2 in the Appendix for the variable definitions; standard errors are in brackets under the coefficients; $* * *, * *, *$ denote statistical significance at the $1 \%, 5 \%$ and $10 \%$ test level, respectively. Firms are divided into low and high non-green innovation intensive firms based on the median firm's non-green innovation sales per capita, which is 32 ' $341 €$. 